\title{
APLIKASI DEBIT ALIRAN MENGGUNAKAN KOEFISIEN DASAR DENGAN DIDASARKAN BENTUK KONFIGURASI DASAR SALURAN
}

\author{
Hari Wibowo ${ }^{1}$ \\ 1Dosen Fakultas Teknik Jurusan Sipil Universitas Tanjungpura Pontianak
}

\begin{abstract}
Abstrak
Kekasaran dasar saluran sangat berpengaruh pada karakteristik aliran, terutama dalam menghitung kecepatan dan debit aliran. Kekasaran dasar saluran dinyatakan dalam koefisien kekasaran. Koefisien kekasaran saluran yang digunakan dalam aliran seragam adalah nilai koefisien kekasaran Manning (n). Banyak penelitian yang dilakukan untuk mendapatkan nilai koefisien kekasaran Manning. Pengunaan koefisien kekasaran Manning saat ini hanya didasarkan $n$ tabel. Sedangkan nilai $n$ tabel Manning hanya disarankan untuk saluran kondisi baik. Penerapan $n$ tabel Manning pada saluran alami memberikan hasil yang kasar, karena keadaan aliran lebih banyak tergantung pada faktor yang tidak diketahui. Diantaranya adanya bentuk konfigurasi dasar, dan penelitian sebelumnya belum ada yang memperhitungkannya. Tujuan penelitian adalah untukmendapatkan suatu rumusan empiris nilai koefisien kekasaran Manning saluran alam berdasarkan modifikasi koefisien kekasaran Manning, yang berkaitan butiran dasar dan bentuk dasar yang ada dilapangan. Metode yang akan dilaksanakan berupa pengambilan data lapangan dalam upaya mencari hubungan bentuk bentuk dasar saluran terhadap koefisien kekasaran dasar material non kohesif. Aplikasi penerapan rumusan akan dilakukan pada studi kasus Sungai Jawi dan Parit Tokaya di kota Pontianak.
\end{abstract}

Kata kunci: Kekasaran dasar, bentuk dasar, koefisien kekasaran Manning

\begin{abstract}
The channel bed roughness is very influential on flow characteristics, especially in calculating the velocity and flow rate. The bed roughness of the channel is expressed in the roughness coefficient. The channel roughness coefficient used in uniform flow is the Manning (n) roughness coefficient value. A lot of research is done to get the Manning roughness coefficient value. The current Manning roughness coefficient is only based on $n$ tables. While the value of the Manning table is only recommended for good channel conditions. Application of Manning tables on natural channels gives rough results, because the flow state depends more on unknown factors. Among them is the form of basic configuration, and no previous research has taken into account. The aim of the study was to obtain an empirical formula for Manning's roughness coefficient value of natural channels based on the modification of Manning's roughness coefficient, which relates the basic grain and the basic form that exists in the field. The method to be implemented is in the form of field data collection in an effort to find the relationship between the shape of the basic channel shape and the basic roughness coefficient of non-cohesive material. The application of the formulation application will be carried out in the case study of Sungai Jawi and Parit Tokaya in Pontianak.
\end{abstract}

Keywords: author guidelines; Teknik journal; article template

\section{Pendahuluan}

Aliran pada saluran aluvial material lepas non-kohesif, umumnya mengalir dalam satu arah dan kompleks (Wibowo et al., 2017; Best, 2005). Interaksi yang

\footnotetext{
1) Penulis Korespondensi.

E-mail: Hariwibowo13@yahoo.com
}

kompleks antara aliran dan angkutan sedimen menimbulkan berbagai jenis bentuk konfigurasi dasar (Hölscher, 2016; Naqshband, 2014; Wang \& White, 1993).

Kekasaran dasar material lepas non kohesif memiliki dua elemen penyusun berbeda. Pertama, partikel merupakan fungsi dari ukuran kekasaran butiran dan bentuk material, dan kedua butiran yang membentuk 
struktur dasar saluran atau kekasaran bentuk (Van der Mark, 2009; Pramono, 2005). Ukuran kekasaran butiran menunjukkan keadaan yang tidak rata pada bagian permukaan dasar saluran (Pramono, 2005). Permukaan dasar ini senantiasa menunjukkan nilai koefisien kekasaran dasar (Nohani and Bakhtiari, 2014; Ansari, 2011; Pramono, 2005).

Kesalahan dalam menentukan besarnya nilai koefisien kekasaran dasar pada saluran aluvial material non kohesif, dapat menimbulkan kesalahan dalam menghitung kecepatan dan debit aliran (Al Adili, 2016; Chow, 1959).

Penentuan nilai koefisien kekasaran dasar sama halnya memperkirakan perlawanan aliran pada dasar saluran (Chow, 1959). Perlawanan aliran dasar saluran terdiri dari beberapa komponen, diantaranya perlawanan gesekan butiran (grain friction), yang pada gilirannya tergantung pada ukuran butiran dasar (Pramono, 2005; Shen, Fehlman, \& Mendoza, 1990). Selanjutnya perlawanan bentuk, karena adanya kekasaran bentuk akibat bentuk konfigurasi dasar, dapat menyebabkan kenaikan signifikan pada fluktuasi permukaan air (Kitsikoudis et al., 2015; Mark, 2009; Morvan et al., 2008; Yen, 2002; Griffiths, 1989)

Metode perkiraan nilai koefisien kekasaran Manning pertama dilakukan oleh Chow (1959). Ia menggunakan nilai pendekatan berdasarkan jenis material dan kekasaraan permukaan saluran. Kekasaran permukaan ini ditandai dengan ukuran dan bentuk butiran bahan, yang membentuk luas basah (Chow, 1959; Wigati \& Kironoto, 2008) 1959; Nurhadini dan Yulistiyanto, 2007). Penentuan koefisien kekasaran Manning selanjutnya disusun dalam $n$ tabel (Chow, 1959). Penggunaan nilai koefisien kekasaran Manning didasarkan $\mathrm{n}$ tabel. hanya disarankan untuk saluran kondisi baik. Pada kondisi aliran saluran alami, penerapan $\mathrm{n}$ tabel Manning sering memberikan hasil sangat kasar. Hal ini dikarenakan keadaan aliran lebih banyak tergantung pada faktor-faktor yang tidak diketahui dari saluran buatan(Putro \& Hadihardaja, 2015; Hari Wibowo, 2015). Penelitian selanjutnya yang dilakukan untuk mendapatkan nilai koefisien kekasaran Manning, diantaranya Limerinos and Resources (1970). Mereka melakukan penelitian koefisien kekasaran Manning di saluran alami atau sungai. Brownlie, (1981) melakukan kajian nilai koefisien kekasaran Manning pada hubungan kedalaman aliran dalam bentuk kondisi hidraulis dan karekteristik material dasar dengan data flume dan lapangan. Jarrett (1985) melakukan kajian nilai koefisien kekasaran Manning pada kemiringan yang besar ( $>$ 0,03). Babai (2008), Md Ali and Saib. (2011) dan Nohani and Bakhtiari (2014) melakukan penerapan rumusan Manning pada kondisi lapangan. Greco et al. (2014) mendapatkan nilai koefisien kekasaran Manning dengan pendekatan metode entropi.
Penelitian yang ada tersebut belum memasukan unsur bentuk konfigurasi dasar.

Pengembangan dan verifikasi dari metode perkiraan nilai koefisien kekasaran Manning terus dilakukan dan masih sangat diperlukan (Bilgil \& Altun, 2008). Kajian mendalam mengenai nilai koefisien kekasaran Manning, dan hubungannya dengan bentuk konfigurasi dasar menjadi sangat penting untuk dikembangkan, sehingga dapat digunakan dalam menentukan nilai koefisien kekasaran yang lebih objektif).

\section{Pustaka dan Metodelogi}

Peta lokasi penelitian

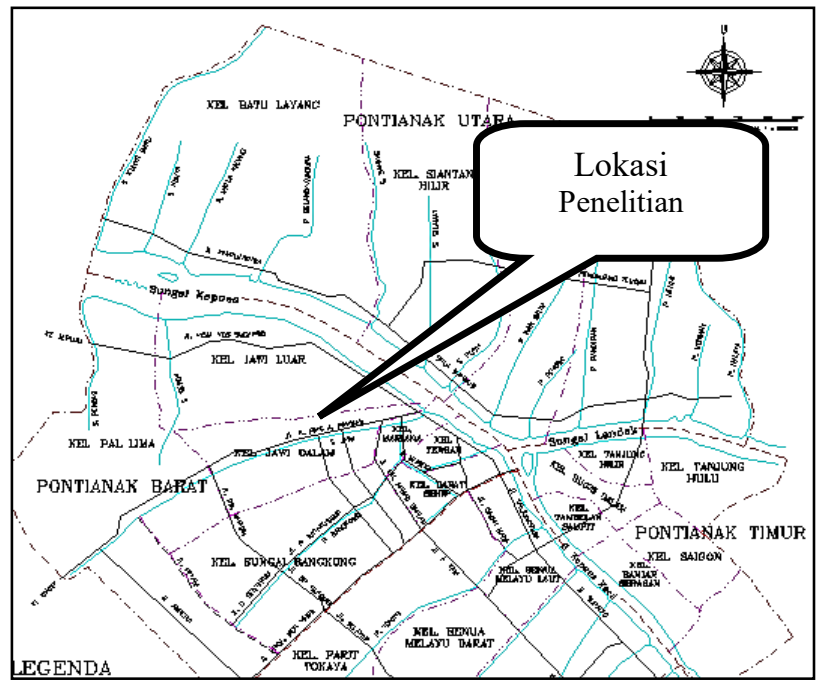

Gambar 1 Lokasi Penelitian

\section{Pertimbangan Teoritis Nilai Koefisien Kekasaran Manning}

Apabila aliran terjadi di dalam suatu saluran, perlawanan akan menghambat aliran air dari hulu ke hilir. Perlawanan tersebut berlawanan dengan komponen gaya gravitasi dalam arah aliran (Chow, 1959).

Aliran seragam terbentuk apabila perlawanan diimbangi oleh gaya gravitasi. Gaya perlawanan tersebut menimbulkan gaya atau tegangan geser yang arahnya sejajar dengan permukaan pada gaya bekerja (Chow, 1959; Wigati and Kironoto, 2008). Tegangan geser merupakan gaya angkut suatu cairan dibagi luas permukaan pada badan saluran oleh aliran (Potter, Wiggert, \& Ramadan, 2016).

Modifikasi pada rumusan nilai koefisien kekasaran Manning, dikembangkan dengan meninjau kembali kajian literatur dan membandingkan hasil dari tinjauan analisis dimensi. Modifikasi ini diperlukan, untuk menjelaskan pengaruh perlawaanan kekasaran butiran dan kekasaran bentuk. Rumusan tersebut ditulis dalam Persamaan 1 dan Persamaan 2 : 


$$
\begin{gathered}
\frac{n^{\prime \prime}}{n^{\prime}}=\left(\frac{R^{\prime \prime}}{R^{\prime}}\right)^{\frac{1}{6}} \frac{a \sqrt{\tau_{\psi}^{\prime \prime}} \sqrt{k_{f} \frac{\rho_{g}}{\rho}}}{\sqrt{2 \Lambda(\cos \beta \tan \phi-\sin \beta)\left(1-\frac{2 k_{f} \rho_{g}}{3 C_{D} \beta}\right)}} \\
\frac{n^{\prime \prime}}{n^{\prime}}=\left(\frac{R^{\prime \prime}}{R^{\gamma}}\right)^{\frac{1}{6}} \frac{a \sqrt{C_{D}} \sqrt{\tau_{*}^{\prime \prime}}}{\sqrt{\left.\frac{\lambda}{d_{g}} a \cos \beta \tan \phi-\sin \beta\right)}}
\end{gathered}
$$

dengan $: \frac{n^{r}}{n^{R}}$ merupakan koefisien kekasaran Manning relative, $R^{\prime}$ jari-jari hidraulik dasar karena butiran (S. Yang, Tan, \& Lim, 2005; S.-Q. Yang \& Tan, 2008). $R^{\prime \prime}$ jari-jari hidraulik dasar karena bentuk. $\mathrm{C}_{\mathrm{D}}=$ koefisien drag (Liu, 2001)

\section{Rumusan Pemisahan Linear Bajorunas (1952) dan} Talebbeydokhti et al (2006)

Bajorunas (1952) dan Talebbeydokhti et al. (2006) telah meneliti mengenai pemisahan pada nilai koefisien kekasaran Manning. Rumusan pemisahan linaer, sebagaimana yang ditunjukan pada Persamaan 3 :

$$
\mathrm{n}=\mathrm{n}^{r}+\mathrm{n}^{\prime \prime}
$$

dimana :

$\mathrm{n}^{\prime}=$ perlawanan butiran dasar yang berhubungan dengan kekasaran butiran.

$\mathbf{n}^{\prime \prime}=$ perlawanan aliran yang berkaitan dengan keberadaan perlawanan bentuk.

Beberapa peneliti telah menghubungkan kekasaran butiran dasar dengan ukuran material dasar saluran, pada nilai koefisien kekasaran Manning. Rumusan tersebut dikembangkan dari rumusan Strickler (1923) dalam (Yen, 1992). Penelitian nilai koefisien kekasaran Manning tersebut, sebagaiman terlihat pada Tabel 1.

Tabel 1. Nilai Koefisien Kekasaran Manning ( $\left.n^{\prime}\right)$ berdasarkan pada Persamaan Strickler (Nohani, 2015)

\begin{tabular}{|l|l|c|}
\hline \multicolumn{1}{|c|}{ Peneliti } & \multicolumn{1}{c|}{ Rumusan } & unit \\
\hline Keulegan (1938) & $n^{\prime}=0.039 d_{50}{ }^{1 / 6}$ & $\mathrm{~m}$ \\
\hline MPM (1948) & $n^{l}=0,038 d_{90}{ }^{1 / 6}$ & $\mathrm{~m}$ \\
\hline Bajorunas (1952) & $n^{r}=0.034 d_{50}{ }^{1 / 6}$ & $\mathrm{~m}$ \\
\hline Henderson(1966) & $n^{l}=0.034 d_{50}{ }^{1 / 6}$ & $\mathrm{ft}$ \\
\hline Simons - Senturk (1976) & $n^{l}=0.047 d_{50}{ }^{1 / 6}$ & $\mathrm{~m}$ \\
\hline Raudkidvi (1976) & $n^{f}=0,042 d_{50}{ }^{1 / 6}$ & $\mathrm{~m}$ \\
\hline Bajorunas (1952) & $n^{f}=0.034 d_{50}{ }^{1 / 6}$ & $\mathrm{~m}$ \\
\hline Wong dan Parker, (2006) & $n^{l}=0.043 d_{50}{ }^{1 / 6}$ & $\mathrm{~m}$ \\
\hline
\end{tabular}

dengan $n^{\prime}=$ perlawanan yang dikarenakan kekasaran butiran dan $k_{g}^{r}=$ kekasaran dasar berkaitan dengan butiran.

\section{Nilai Koefisien Kekasaran Manning}

Koefisien kekasaran $\mathrm{n}$ Manning dikembangkan oleh beberapa ahli beberapa ahli hidraulik dalam skala laboratorium, diantaranya di Illinois dan New York (Schnepper and Chow, 1954) dalam (Chow, 1959). Chow (1959), memperpanjang ruang lingkup dan memberi suatu Tabel, yang agak komprehensif dari nilai n, maka dibuatlah suatu daftar nilai-nilai koefisien kekasaran Manning (n) untuk saluran dengan bahan pembentuk saluran yang berbeda. Berikut ini adalah beberapa dari Tabel n Manning sebagaimana Tabel 2.

\begin{tabular}{|c|c|c|c|}
\hline \multirow{2}{*}{ Tipe saluran dan jenis bahan } & \multicolumn{3}{|c|}{$\begin{array}{c}\text { Nilai Koefisien } \\
\text { Kekasaran n }\end{array}$} \\
\hline & Min & $\begin{array}{l}\text { Nor } \\
\text { mal }\end{array}$ & $\begin{array}{l}\text { Maks } \\
\text { imum }\end{array}$ \\
\hline $\begin{array}{l}\text { Tanah, lurus dan seragam } \\
\text { - } \quad \text { Bersih baru } \\
\text { - } \quad \text { Bersih telah melapuk } \\
\text { - } \quad \text { Berkerikil } \\
\text { Saluran alam } \\
\text { - } \quad \text { Bersih lurus } \\
\text { - } \quad \text { Bersih, berkelok-kelok } \\
\text { - } \quad \text { Banyak tanaman penggang }\end{array}$ & $\begin{array}{l}0,016 \\
0,018 \\
0,022 \\
0,025 \\
0,033 \\
0,050\end{array}$ & $\begin{array}{l}0,018 \\
0,022 \\
0,025 \\
0,030 \\
0,040 \\
0,070\end{array}$ & $\begin{array}{l}0,020 \\
0,025 \\
0,030 \\
0,033 \\
0,045 \\
0,080\end{array}$ \\
\hline
\end{tabular}

Tabel 2. Nilai Koefisien Kekasaran Manning n (Chow, 1959).

\section{Metode Penjumlahan Komponen pada Perlawanan Saluran Aluvial.}

Metode penjumlahan komponen perlawanan saluran aluvial ini telah diakui secara luas oleh para ahli hidraulik sebagai suatu prinsip pendekatan pada penjumlahan komponen perlawanan (Meyer-Peter \& Müller, 1948; Einstein, 1950). Prinsip ini telah dikembangkan pada komponen perlawanan alami dengan dasar kaku dan komponen perlawanan alami dengan dasar fleksibel (Einstein, 1950; Yen, 2002; S.-Q. Yang \& Tan, 2008)

Einstein (1950) juga memisahkan jari-jari hidraulis dibagi lagi menjadi dua komponen, sebagaimana Persamaan 4:

$$
\mathrm{R}=\mathrm{R}^{\prime}+\mathrm{R}^{\prime \prime}
$$

dimana $R^{\prime}$ adalah jari-jari hidraulik yang berkaitan dengan gesekan butiran dan $R^{\prime \prime}$ adalah jari-jari hidraulik yang berkaitan dengan bentuk

Einstein (1950) dan Engelund (1966) mengusulkan persamaan yang digunakan untuk memperoleh jari-jari hidraulik berkaitan dengan gesekan butiran, sebagaimana Persamaan 5 :

$$
\frac{V}{V_{*}^{\prime}}=5,75 \log \left(12,27 \frac{R^{\prime}}{k_{g}} x\right) ; V_{s}^{\prime}=\sqrt{g^{R^{\prime} S}}
$$


Einstein dan Barbarossa (1952) melanjutkan penelitian Einstein (1950) dengan menggunakan data keduanya, yakni data flume dan lapangan. Mereka mengungkapkan bahwa perlawanan bentuk (form resistance) merupakan fungsi pada besarnya angkutan sedimen, sebagaimana Persamaan 6 ;

$$
\frac{v}{V_{*}{ }^{\prime \prime}}=\phi\left(\psi^{\prime}\right)=\left(\frac{\gamma_{s}-\gamma}{\gamma}\right) \frac{d_{z s}}{s_{f} R^{\prime}}
$$

Dimana

$V_{*}^{\prime}=$ kecepatan geser dikarenakan gesekan butiran

$\boldsymbol{R}^{\prime}=$ jari - jari hidraulis dikarenakan gesekan kulit (skin friction).

$k_{g}=$ kekasaran butiran eqivalen $=d_{65}$ dan $d_{35}$

$x=$ fungsi pada $k_{s} / \delta$

$\delta=$ ketebalan lapisan batas $\delta=11,6 \mathrm{v} / V_{\psi}{ }^{\wedge}$

$V_{*}{ }^{\prime \prime}=$ kecepatan geser dikarenakan kekasaran bentuk.

$\psi^{s}=$ parameter aliran karena kekasaran bentuk

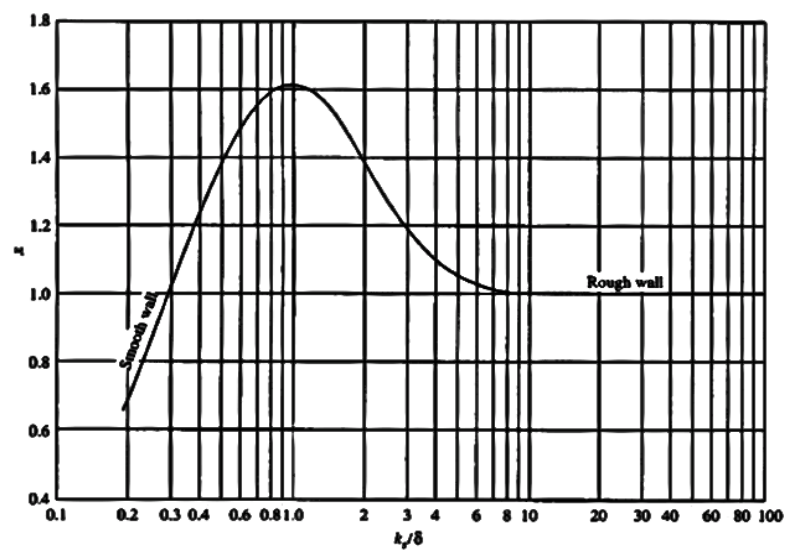

Gambar 2 Faktor Koreksi Distribusi Kecepatan (Einstein, 1950)

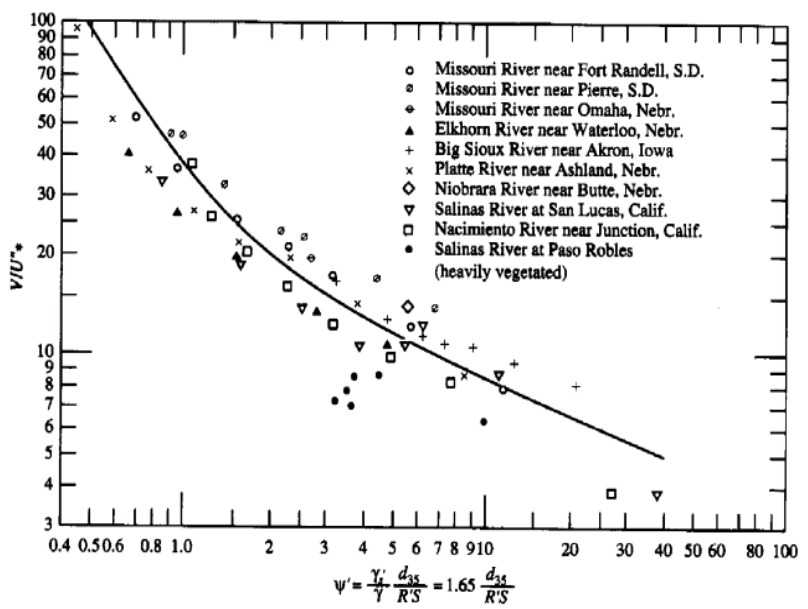

Gambar 3 Kehilangan Gesekan dikarenakan Ketidakteraturan Saluran sebagai fungsi Angkutan Sedimen (Einstein and Barbarossa, 1952)

\section{Prosedur penelitian}

Langkah -langkah penelitian sebegai berikut :

a) Metode yang digunakan dalam penelitian ini adalah penerapan lapangan

b) Pelaksanaan penelitian di lapangan akan di lakukan di dua tempat, yakni Parit Sei Jawi di Jalan di Hasanudin dan Parit Tokaya Kota Pontianak Kalimantan Barat

c) Metode lapangan dengan cara pengambilan data kecepatan dan debit aliran dengan menggunakan alat current meter

d) Pelaksanaan di lapangan meliputi langkah-langkah sebagai berikut:

(1) Menentukan lokasi pengukuran.

(1) Ukur penampang melintang tiap titik saluran

(1) Bagi penampang saluran tersebut dalam beberapa segmen atau pias yakni 1/6 L, 1/3 L, 1/2 L, 2/3 L, dan $5 / 6 \mathrm{~L}$.

(1) Ukur kedalaman dari muka air

(1) Letakkan alat Current meter dipermukaan; pada kedalaman $0,2 \mathrm{~h} ; 0,6 \mathrm{~h} ; 0,8 \mathrm{~h}$ dan didasar saluran pada tiap segmen atau pias.

(1) Pengukuran dilakukan pada waktu Pasang dan pada waktu Surut

e) Kecepatan aliran di setiap titik dihitung berdasarkan jumlah putaran baling-baling selama 50 detik.

f. Penentuan koefisien Manning didapat berdasarkan kompilasi kecepatan aliran dan dimensi penampang dengan cara seperti berikut;

(1) Hitung kecepatan aliran rata-rata tiap penampang dengan rumus; $Q=\bar{V} A$ dan

(1) Hitung nilai koefisien kekasaran Manning dengan persamaan; $\bar{V}=(1 / \mathrm{n})\left(\mathrm{R}^{2 / 3}\right)\left(\mathrm{S}^{1 / 2}\right)$ dan

$$
\mathrm{n}=\left(\mathrm{R}^{2 / 3}\right)\left(\mathrm{S}^{1 / 2}\right) /(\bar{V})
$$

(1) Rata-ratakan nilai $n$ untuk seluruh titik

$$
\text { pengukuran }: \mathrm{n}=\Sigma \mathrm{n} /(\text { jumlah titik) }
$$

(1) Selanjutnya didapatkan nilai koefisien Manning di lapangan.

\section{Pendekatan Statistik}

Penyajian data statistik data ditampilkan dalam bentuk penyajian dengan tabel dan gambar.

Pengujian uji kesalahan dalam perhitungan dilakukan dengan membandingkan hasil nilai koefisien kekasaran dasar hitungan terhadap data rumusan Manning.

(1) Perhitungan Nilai Rasio $\mathrm{n}$ data dan $\mathrm{n}$ dihitung dengan $\mathrm{n}$ rumus empiris

Perhitungan nilai koefisien kekasaran (n) hasil hitungan, dibandingkan dengan nilai koefisien kekasaran Manning. Rumusan yang digunakan sebagaimana Persamaan 9 :

$$
\text { Rasio koe kekasaran }=\mathrm{n} \text { hitung } / \mathrm{n} \text { data }
$$

(1) Perhitungan Persentase Penyimpangan dengan nilai koefisien kekasaran Manning 
Penentuan persentase penyimpangan nilai koefisien kekasaran Manning, dimaksudkan untuk memudahkan, dalam meneliti keakuratan atau kebenaran hasil hitungan. Metode yang digunakan adalah metode kesalahan absolute rata-rata (KAR). Rumusan kesalahan absolute rata-rata ini didasarkan persentase penyimpangan. Hal ini digunakan untuk mempermudah dalam meneliti keakuratan atau kebenaran hitungan. Rumusan ditulis dalam Persamaan 10:

$$
(\mathrm{KAR})=\frac{1}{\mathrm{~N}} \sum \frac{\left(\mathrm{n}_{\text {dihitung }}-\mathrm{n}_{\text {dgta }}\right)}{n_{\text {datg }}} \times 100 \%
$$

\section{Data Percobaan}

Data percobaan pada sampel percobaan, selanjutnya dilakukan analisa butiran, seperti Tabel 3 .

Tabel 3. Hasil Analisis Butiran Material Dasar

\begin{tabular}{|c|c|c|}
\hline Diameter (mm) & $\begin{array}{c}\text { Pasir Sei Jawi } \\
(\mathbf{A})\end{array}$ & $\begin{array}{c}\text { Pasir Parit } \\
\text { Tokaya (B) }\end{array}$ \\
\hline $\mathrm{d}_{16}$ & $0.010 \mathrm{~mm}$ & $0.040 \mathrm{~mm}$ \\
\hline $\mathrm{d}_{35}$ & $0.150 \mathrm{~mm}$ & $0.240 \mathrm{~mm}$ \\
\hline $\mathrm{d}_{50}$ & $0.280 \mathrm{~mm}$ & $0.328 \mathrm{~mm}$ \\
\hline $\mathrm{d}_{65}$ & $0.420 \mathrm{~mm}$ & $0.450 \mathrm{~mm}$ \\
\hline $\mathrm{d}_{84}$ & $0.820 \mathrm{~mm}$ & $0.681 \mathrm{~mm}$ \\
\hline $\mathrm{d}_{90}$ & $0.900 \mathrm{~mm}$ & $0.770 \mathrm{~mm}$ \\
\hline
\end{tabular}

Hasil uji pemeriksaan material dasar di Laboratorium Mekanika Tanah Universitas Tanjungpura, sebagaimana yang ditunjukan Tabel 4.

Tabel 4 Hasil Perhitungan Karakteristik pada Material Dasar

\begin{tabular}{|c|c|c|c|c|}
\hline $\begin{array}{c}\text { Nama } \\
\text { sampel }\end{array}$ & $\begin{array}{c}\text { Berat } \\
\text { volume } \\
\left(\gamma_{s}\right) \mathrm{g} / \mathrm{cm}^{3}\end{array}$ & Gs & Porositas & $\begin{array}{c}\phi \\
\text { derajat }\end{array}$ \\
\hline Pasir (A) & 1,032 & 1,908 & 0,797 & $30^{\circ}$ \\
\hline Pasir (B) & 1,302 & 2,678 & 0,791 & $31,04^{\circ}$ \\
\hline
\end{tabular}

\section{Kecepatan Aliran pada Penampang Saluran}

Kecepatan aliran diukur melalui aliran permukaan sebagai kecepatan aliran permukaan. Kecepatan aliran tidak sama pada setiap kedalaman saluran atau sungai. Aliran melalui saluran terbuka, distribusi kecepatan aliran tergantung pada banyak faktor seperti bentuk saluran, kekasaran dasar dan juga debit aliran.

(1) Lokasi Sungai Jawi

Hasil pengukuran kecepatan aliran pada lokasi Sungai Jawi Seperti Tabel 5 dan Tabel 6
Tabel 5 Resume Perhitngan Debit Aliran pada Saluran Parit Sungai Jawi Pontianak

\begin{tabular}{|r|c|c|c|c|c|c|}
\hline No & $\begin{array}{c}\text { Lebar } \\
\mathrm{b}(\mathrm{m})\end{array}$ & $\begin{array}{c}\mathrm{h} \\
(\mathrm{m})\end{array}$ & $\begin{array}{c}\mathrm{S} \\
(\mathrm{m} / \mathrm{m})\end{array}$ & $\begin{array}{c}\mathrm{R} \\
(\mathrm{m})\end{array}$ & $\begin{array}{c}\mathrm{V} \\
(\mathrm{m} / \mathrm{s})\end{array}$ & $\begin{array}{c}\mathrm{Q} \\
\left(\mathrm{m}^{3} / \mathrm{s}\right)\end{array}$ \\
\hline 1 & 16.55 & 1.218 & 0.000009 & 0.427 & 0.435 & 8.613 \\
\hline 2 & 16.55 & 1.165 & 0.000030 & 0.429 & 0.445 & 8.691 \\
\hline 3 & 15.60 & 1.158 & 0.000012 & 0.419 & 0.735 & 12.839 \\
\hline 4 & 15.60 & 1.105 & 0.000009 & 0.401 & 0.783 & 13.066 \\
\hline 5 & 16.37 & 1.053 & 0.000033 & 0.384 & 0.723 & 11.990 \\
\hline 6 & 16.37 & 0.954 & 0.000033 & 0.357 & 0.760 & 11.447 \\
\hline
\end{tabular}

$\mathrm{h}=\operatorname{Kedalaman}(\mathrm{m}) ; \mathrm{S}=$ kemiringan dan $\mathrm{R}=$ jari hidrolis $(\mathrm{m})$

(1) Lokasi Parit Tokaya

Tabel 6 Data Hasil Perhitungan Luas Penampang dan Debit Aliran Parit Tokaya

\begin{tabular}{|l|c|c|c|c|}
\hline \multicolumn{1}{|c|}{ Lokasi } & $\begin{array}{c}\mathrm{V} \\
(\mathrm{m} / \mathrm{det})\end{array}$ & $\begin{array}{c}\mathrm{h} \\
(\mathrm{m})\end{array}$ & $\mathrm{b}(\mathrm{m})$ & $\begin{array}{c}\mathrm{Q} \\
\left(\mathrm{m}^{3} / \mathrm{s}\right)\end{array}$ \\
\hline Mall Ramayana & 0.255 & 0.841 & 12.800 & 3.345 \\
\hline Pasar Flamboyan & 0.363 & 0.923 & 11.400 & 4.281 \\
\hline Gedung Kartini & 0.147 & 0.552 & 13.870 & 1.385 \\
\hline Simpang Purnama & 0.214 & 0.856 & 6.900 & 1.491 \\
\hline Hulu Parit Tokaya & 0.270 & 0.517 & 4.200 & 0.664 \\
\hline
\end{tabular}

\section{Perhitungan Koefisien Kekasaran Manning pada} Tiap Penampang

Persamaan yang digunakan untuk menghitung koefisin kekasaran menggunakan rumusan Manning (Pers. 7). Persamaan Manning menggunakan parameter kecepatan aliran rata-rata $(\bar{V})$, jari-jari hidrolik (R), dan kemiringan saluran (S).

Hasil Perhitungan pada masing-masing lokasi sebagaimana Tabel 7 dan Tabel 8

Tabel 7 Hasil Perhitungan Koefisien Kekasaran Manning Parit Sungai Jawi Pontianak

\begin{tabular}{|r|c|c|c|c|c|}
\hline No & $\mathrm{h}(\mathrm{m})$ & $(\mathrm{S})$ & \multicolumn{1}{|c|}{$\begin{array}{c}\mathrm{V} \\
(\mathrm{m} / \mathrm{s})\end{array}$} & $\begin{array}{c}\text { Debit } \\
\mathrm{Q}\left(\mathrm{m}^{3} / \mathrm{s}\right)\end{array}$ & $\begin{array}{c}\text { Koef. } \\
\text { Kekasaran } \\
\text { Maning } \mathrm{n}\end{array}$ \\
\hline 1 & 1.218 & 0.000009 & 0.435 & 8.613 & 0.008 \\
\hline 2 & 1.165 & 0.000030 & 0.445 & 8.691 & 0.014 \\
\hline 3 & 1.158 & 0.000012 & 0.735 & 12.839 & 0.005 \\
\hline 4 & 1.105 & 0.000009 & 0.783 & 13.066 & 0.004 \\
\hline 5 & 1.053 & 0.000033 & 0.723 & 11.990 & 0.008 \\
\hline 6 & 0.954 & 0.000033 & 0.760 & 11.447 & 0.007 \\
\hline
\end{tabular}


Tabel 8. Hasil Perhitungan Koefisien Kekasaran Manning Parit Tokaya Kota Pontianak

\begin{tabular}{|c|l|c|c|}
\hline No & \multicolumn{1}{|c|}{ Lokasi } & $\begin{array}{c}\mathrm{V} \\
(\mathrm{m} / \mathrm{s})\end{array}$ & $\begin{array}{c}\text { Koef. } \\
\text { Kekasaran } \\
\text { Maning } \mathrm{n}\end{array}$ \\
\hline 1 & Mall Ramayana & 0.255 & 0.0635 \\
\hline 2 & Pasar Flamboyan & 0.363 & 0.0476 \\
\hline 3 & Gedung Kartini & 0.147 & 0.0500 \\
\hline 4 & Simpang Purnama & 0.214 & 0.0460 \\
\hline 5 & Hulu Parit Tokaya & 0.270 & 0.0260 \\
\hline
\end{tabular}

\section{Perhitungan Nilai Koefisien Kekasaran Saluran Dengan Persamaan Cowan}

Rumus yang digunakan;

$n=\left(n_{0}+n_{1}+n_{2}+n_{3}+n_{4}\right) m_{5}$ Dari analisa diatas

didapat nilai n; $n=\left(n_{0}+n_{1}+n_{2}+n_{3}+n_{4}\right) m_{5}$

$=(0,020+0,005+0,000+0,000+0,000) \times 1,000$

$=0,025$

12. Penentuan Nilai Koefisien Kekasaran Saluran.

Nilai koefisien kekasaran Manning untuk saluran yang dilapisi, dipoles, yang terbuat dari pasangan batu pecah yang disemen. Nilai-nilai berikut merupakan nilai koefisien kekasaran Manning menurut Tabel Chow (1959), untuk saluran alami, sebagaimana Tabel 2. Resume hasil kajian koefisien Manning seperti pada Tabel 9

Tabel 9 Resume Nilai $n$ Tabel 2, Persamaan Cowan, dan Pengukuran Lapangan

\begin{tabular}{|c|c|c|c|c|c|}
\hline \multicolumn{3}{|c|}{ Tabel 2.2 } & \multirow{2}{*}{$n$ Pers. } \\
\cline { 5 - 6 } & Cowan & $\begin{array}{c}\text { Sungai } \\
\text { Jawi }\end{array}$ & $\begin{array}{c}\text { Parit } \\
\text { Tokaya }\end{array}$ \\
\hline 0,025 & 0,030 & 0,033 & 0,025 & 0,008 & 0,0466 \\
\hline
\end{tabular}

\section{Pendekatan pada Mekanisme Perlawanan Aliran atas Pengerakan Dasar.}

Perhitungan perlawanan aliran yang ditimbulkan oleh butiran material dasar saluran dan ketidakteraturan bentuk dasar, digunakan rumusan Einstein-Barbarossa. Hasil perhitungan pemisahan jari -jari hidraulik akibat kekasaran butiran dan kekasaran bentuk berkaitan ukuran diameter butiran, sebagaimana Tabel 10 dan Tabel 11
Tabel 10. Hasil perhitungan Pemisahan Jari -Jari Hidraulik Akibat Kekasaran Butiran dan Kekasaran Bentuk Berkaitan Ukuran diameter Butiran Sungai Jawi

\begin{tabular}{|c|c|c|r|c|c|}
\hline No & $\begin{array}{c}\mathbb{R}^{\prime} \\
(\mathrm{m})\end{array}$ & $\begin{array}{c}\mathbf{V}^{r} \\
(\mathrm{~m} / \mathrm{s})\end{array}$ & $\Psi^{r}$ & $\begin{array}{c}\mathbb{R}^{R I} \\
(\mathrm{~m})\end{array}$ & $\begin{array}{c}\mathrm{Q} \\
\left(\mathrm{m}^{3} / \mathrm{s}\right)\end{array}$ \\
\hline 1 & 0.0631 & 0.0024 & 505.46 & 1.155 & 8.6134 \\
\hline 2 & 0.1028 & 0.0055 & 94.66 & 1.062 & 8.6906 \\
\hline 3 & 0.0861 & 0.0032 & 281.58 & 1.072 & 12.8392 \\
\hline 4 & 0.0732 & 0.0025 & 436.06 & 1.032 & 13.0664 \\
\hline 5 & 0.1289 & 0.0065 & 67.60 & 0.924 & 11.9897 \\
\hline 6 & 0.1256 & 0.0064 & 69.41 & 0.828 & 11.4468 \\
\hline
\end{tabular}

Tabel 11. Hasil perhitungan Pemisahan Jari -Jari Hidraulik Akibat Kekasaran Butiran dan Kekasaran Bentuk Berkaitan Ukuran diameter Butiran Parit Tokaya

\begin{tabular}{|c|c|c|c|c|c|}
\hline No & $\begin{array}{c}\mathbb{R}^{I} \\
(\mathrm{~m})\end{array}$ & $\begin{array}{c}\mathrm{V}_{*}{ }^{r} \\
(\mathrm{~m} / \mathrm{s})\end{array}$ & $\Psi^{E}$ & $\begin{array}{c}\mathbb{R}^{E I} \\
(\mathrm{~m})\end{array}$ & $\begin{array}{c}\mathrm{Q} \\
\left(\mathrm{m}^{3} / \mathrm{s}\right)\end{array}$ \\
\hline 1 & 0.091 & 0.017 & 11.219 & 0.750 & 3.345 \\
\hline 2 & 0.120 & 0.020 & 8.508 & 0.803 & 4.281 \\
\hline 3 & 0.038 & 0.007 & 74.870 & 0.514 & 1.385 \\
\hline 4 & 0.058 & 0.008 & 49.231 & 0.798 & 1.491 \\
\hline 5 & 0.040 & 0.007 & 70.208 & 0.477 & 0.664 \\
\hline
\end{tabular}

\section{Nilai Koefisien Kekasaran Manning Berdasarkan Perlawanan Butiran}

Nilai koefisien kekasaran Manning dengan perlawanan akibat butiran, maka diperlukan nilai jari-jari hidraulis dasar perlawanan butiran $\left(\mathrm{R}^{\prime}\right)$.

$$
n^{\prime}=\frac{R^{g^{1 / 6}}}{5,75 \sqrt{g} \log \left(12,27 \frac{R^{\prime}}{k_{g}} x\right)}
$$

Nilai koefisien kekasaran Manning ( $n$ ') Penelitian Terdahulu pada Tabel 2.2. Hasil penelitian terdahulu disajikan dalam Tabel 12

Tabel 12 Nilai Koefisien Kekasaran Manning ( $n^{\prime}$ ) Penelitian Terdahulu

\begin{tabular}{|l|c|c|c|c|}
\hline \multirow{2}{*}{$\begin{array}{c}\text { Peneliti } \\
\text { Terdahulu }\end{array}$} & \multicolumn{2}{|c|}{ Dia. butiran (d) } & \multicolumn{2}{c|}{ Persamaan 11 } \\
\cline { 2 - 3 } & $\begin{array}{c}\text { Sungai } \\
\text { Jawi }\end{array}$ & $\begin{array}{c}\text { Parit } \\
\text { Tokaya }\end{array}$ & $0.28 \mathrm{~mm}$ & $0.32 \mathrm{~mm}$ \\
\hline $\begin{array}{l}\text { Keulegan } \\
(1938)\end{array}$ & 0.0100 & 0.0102 & & \\
\hline MPM (1948) & 0.0118 & 0.0115 & 0.0113 & 0.0102 \\
\hline
\end{tabular}


Tabel 12 Nilai Koefisien Kekasaran Manning ( $n^{\prime}$ ) Penelitian Terdahulu (lanjutan)

\begin{tabular}{|l|c|c|c|c|}
\hline \multirow{2}{*}{\begin{tabular}{c}
\multirow{2}{*}{$\begin{array}{c}\text { Peneliti } \\
\text { Terdahulu }\end{array}$} \\
\cline { 2 - 5 } $\begin{array}{l}\text { Henderson } \\
\text { (1966) }\end{array}$
\end{tabular}} & $\begin{array}{c}\text { Sungai } \\
\text { Jawi }\end{array}$ & $\begin{array}{c}\text { Parit } \\
\text { Tokaya }\end{array}$ & $0.28 \mathrm{~mm}$ & $0.32 \mathrm{~mm}$ \\
\hline $\begin{array}{l}\text { Simons - } \\
\text { Senturk (1976) }\end{array}$ & 0.0106 & 0.0109 & & \\
\hline $\begin{array}{l}\text { Raudkidvi } \\
\text { (1976) }\end{array}$ & 0.0107 & 0.0110 & 0.0113 & 0.0102 \\
\hline $\begin{array}{l}\text { Bajorunas } \\
\text { (1952) }\end{array}$ & 0.0106 & 0.0109 & & \\
\hline $\begin{array}{l}\text { Wong \& Parker } \\
\text { (2006) }\end{array}$ & 0.0110 & 0.0113 & & \\
\hline
\end{tabular}

Berdasarkan pada Tabel 12, menunjukan nilai koefisien kekasaran Manning berkaitan butiran $\left(n^{1}\right)$ mendekati hasil penelitian, seperti yang dilakukan Keulegan (1938), yakni $\mathbf{n}^{\prime}=0,038 d_{50}^{1 / 6}$.

\section{Nilai Koefisien Kekasaran Manning Berdasarkan Perlawanan Bentuk}

perlawanan aliran dasar dalam kaitannya dengan keberadaan bentuk dasar dan perubahannya yang dikenal dengan kekasaran bentuk ( $n$ ”). Bajorunas (1952) telah mengembangkan nilai perlawanan aliran karena keberadaan bentuk berkaitan dengan parameter intensitas aliran. Rumusan yang dinyatakan dalam Persamaan 12

$$
\mathrm{n}^{E F}=\Phi\left(\frac{\mathrm{R}^{\prime} \mathrm{S}_{\mathrm{f}}}{1,6 \mathrm{Rd} \mathrm{g}}\right)=\frac{1}{\mathrm{~V}} \cdot \mathrm{R}^{\mathrm{nn} / 2 / 3} \mathrm{~S}^{1 / 2}
$$

Hasil penelitian Bajorunas (1952) disajikan dalam Tabel 13 dan Tabel 14

Tabel 13 Nilai Koefisien Manning karena Perlawanan Bentuk ( $\left.\mathbf{n}^{\prime \prime}\right)$ Sungai Jawi

\begin{tabular}{|c|c|c|c|}
\hline $\begin{array}{c}\text { Kemiringan } \\
(\mathrm{S})\end{array}$ & $\begin{array}{c}\text { Koefisien } \\
\text { Manning } \\
\text { karena } \\
\text { Perlawanan } \\
\text { Bentuk }\left(\mathrm{n}^{n}\right)\end{array}$ & $\begin{array}{c}\text { Perlawanan } \\
\text { butiran } \\
\mathbf{n}^{\prime}\end{array}$ & $\begin{array}{c}\text { Nilai } \\
\text { Koefisien } \\
\text { Kekasaran } \\
\text { Manning } \\
\mathrm{n}=\mathbf{n}^{\prime}+\mathrm{n}^{\prime \prime}\end{array}$ \\
\hline 0.000009 & 0.009 & 0.0106 & 0.0196 \\
\hline 0.000030 & 0.005 & 0.0106 & 0.0156 \\
\hline 0.000012 & 0.007 & 0.0106 & 0.0176 \\
\hline 0.000009 & 0.007 & 0.0106 & 0.0176 \\
\hline 0.000033 & 0.004 & 0.0106 & 0.0146 \\
\hline 0.000033 & 0.004 & 0.0106 & 0.0146 \\
\hline
\end{tabular}

Tabel 14 Nilai Koefisien Manning karena Perlawanan Bentuk ( $\left.\mathbf{n}^{\prime \prime}\right)$ Parit Tokaya

\begin{tabular}{|c|c|c|c|}
\hline $\begin{array}{c}\text { Kemiringan } \\
(\mathrm{S})\end{array}$ & $\begin{array}{c}\text { Koefisien } \\
\text { Manning } \\
\text { karena } \\
\text { Perlawanan } \\
\text { Bentuk }\left(\mathrm{n}^{r r}\right)\end{array}$ & $\begin{array}{c}\text { Perlawanan } \\
\text { butiran } \\
\mathrm{n}^{r}\end{array}$ & $\begin{array}{c}\text { Nilai } \\
\text { Koefisien } \\
\text { Kekasaran } \\
\text { Manning } \\
\mathrm{n}=\mathrm{n}^{r}+\mathrm{n}^{r s}\end{array}$ \\
\hline 0.000331 & 0.0425 & 0.0109 & 0.0534 \\
\hline 0.000331 & 0.0373 & 0.0109 & 0.0482 \\
\hline 0.000119 & 0.0616 & 0.0109 & 0.0725 \\
\hline 0.000119 & 0.0618 & 0.0109 & 0.0727 \\
\hline 0.000119 & 0.0559 & 0.0109 & 0.0668 \\
\hline
\end{tabular}

Selanjutnya hasil Persamaan 1 dan Persamaan 2, disajikan dalam Tabel 15 dan Tabel 16

Tabel 15 Nilai Koefisien Manning karena Perlawanan Bentuk ( $\left.\mathbf{n}^{\prime \prime}\right)$ Sungai Jawi

\begin{tabular}{|c|c|c|c|}
\hline $\begin{array}{c}\text { Kemiringan } \\
(\mathrm{S})\end{array}$ & $\begin{array}{c}\text { Nilai } \\
\text { Koefisien } \\
\text { Manning } \\
\text { Perlawanan } \\
\text { Bentuk }\left(\mathrm{n}^{E I}\right)\end{array}$ & $\begin{array}{c}\text { Perlawanan } \\
\text { butiran } \\
\mathrm{n}^{s}\end{array}$ & $\begin{array}{c}\text { Nilai } \\
\text { Koefisien } \\
\text { Kekasaran } \\
\text { Manning } \\
\mathrm{n}=\mathrm{n}^{s}+\mathrm{n}^{r s}\end{array}$ \\
\hline 0.000009 & 0.017 & 0.0113 & 0.0283 \\
\hline 0.000030 & 0.020 & 0.0113 & 0.0313 \\
\hline 0.000012 & 0.017 & 0.0113 & 0.0283 \\
\hline 0.000009 & 0.017 & 0.0113 & 0.0283 \\
\hline 0.000033 & 0.019 & 0.0113 & 0.0303 \\
\hline 0.000033 & 0.019 & 0.0113 & 0.0303 \\
\hline
\end{tabular}

Tabel 16 Nilai Koefisien Manning karena Perlawanan

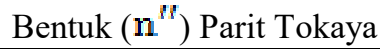

\begin{tabular}{|c|c|c|c|}
\hline $\begin{array}{c}\text { Kemiringan } \\
(\mathrm{S})\end{array}$ & $\begin{array}{c}\text { Koefisien } \\
\text { Manning } \\
\text { Perlawanan } \\
\text { Bentuk } \\
\left(\mathrm{n}^{E F}\right)\end{array}$ & $\begin{array}{c}\text { Perlawanan } \\
\text { butiran } \\
\mathrm{n}^{r}\end{array}$ & $\begin{array}{c}\text { Nilai } \\
\text { Koefisien } \\
\text { Kekasaran } \\
\text { Manning } \\
\mathbf{n}=\mathbf{n}^{E}+\mathrm{n}^{E E}\end{array}$ \\
\hline 0.000331 & 0.047 & 0.01022 & 0.05722 \\
\hline 0.000331 & 0.046 & 0.01022 & 0.05622 \\
\hline 0.000119 & 0.028 & 0.01022 & 0.03822 \\
\hline 0.000119 & 0.021 & 0.01022 & 0.03122 \\
\hline 0.000119 & 0.015 & 0.01022 & 0.02522 \\
\hline
\end{tabular}

16. Analisa Data Pengujian Kesalahan pada Nilai Koefisien Kekasaran Manning

Pengujian uji kesalahan dalam perhitungan dilakukan dengan membandingkan hasil nilai koefisien kekasaran dasar hitungan terhadap data rumusan Manning di lapangan. Pendekatan yang digunakan seperti pada 
Persamaan 9 dan Persamaan 10. Hasil Perhitungan sebagaimana tertuang pada Tabel 17 dan Tabel 18

Tabel 17 Uji Kesalahan Rata-rata Nilai Koefisien Kekasaran Manning Hitungan dan $\mathrm{n}$ data Berdasarkan n Tabel

\begin{tabular}{|r|l|r|r|r|}
\hline $\begin{array}{c}\mathrm{n}_{\text {data }} \\
\text { (Tabel 2) }\end{array}$ & Penelitian & $\mathrm{n}$ hitung & $\begin{array}{c}\text { rasio } \\
\text { nilai } \mathrm{n}\end{array}$ & $\begin{array}{c}\text { Kesalahan } \\
\text { Absolut } \\
\text { Rata-rata } \\
\text { (KAR) (\%) }\end{array}$ \\
\hline 0,030 & Cowan 1956 & 0,025 & 0,833 & 16,667 \\
\hline \multicolumn{5}{|l|}{ n lapangan } \\
\hline 1 & Sei Jawi & 0.0080 & 0,267 & 73.333 \\
\hline
\end{tabular}

\begin{tabular}{|l|l|c|c|r|}
\hline & $\begin{array}{l}\text { Parit } \\
\text { Tokaya }\end{array}$ & 0.0466 & 1.553 & 55.333 \\
\hline \multicolumn{5}{|c|}{} \\
$\mathrm{n}$ akibat perlawanan aliran \\
\hline $\begin{array}{l}\text { Bajorunas } \\
(1952)\end{array}$ & $\begin{array}{l}\text { Sei Jawi } \\
\text { Parit }\end{array}$ & 0.0166 & 0.553 & 44.667 \\
& Tokaya & 0.0672 & 2.240 & 124.00 \\
\hline $\begin{array}{l}\text { Wibowo } \\
(2017)\end{array}$ & Sei Jawi & 0.02948 & 0.983 & 1.733 \\
& Parit & 0.04162 & 1.387 & 38.733 \\
\hline
\end{tabular}

Tabel 18 Uji Kesalahan Rata-rata Nilai Koefisien Kekasaran Manning Hitungan dan n data Berdasarkan n Pengamatan Lapangan

\begin{tabular}{|c|c|c|c|c|}
\hline Penelitian & Lokasi & $\mathrm{n}_{\text {hitungan }}$ & rasio $\frac{\text { nhitungan }}{\text { ndata }}$ & $\begin{array}{c}\text { Kesalahan Absolut Rata-rata } \\
\text { (KAR) (\%) }\end{array}$ \\
\hline n lapangan & Nilai koefi. kekasaran & Cowan 1956 & & \\
\hline Sei Jawi & 0.0080 & 0.025 & 3.125 & \\
\hline Parit Tokaya & 0.0466 & 0.025 & 0.536 & 46.352 \\
\hline \multicolumn{2}{|c|}{ Nilai koefisien kekasaran } & Tabel 17 & & \\
\hline Sei Jawi & 0.0080 & 0.030 & 3.750 & \\
\hline Parit Tokaya & 0.0466 & 0.030 & 0.644 & 35.622 \\
\hline \multicolumn{5}{|c|}{$\mathrm{n}$ akibat perlawanan aliran } \\
\hline \multirow[t]{2}{*}{ Bajorunas (1952) } & Sei Jawi & 0.0166 & 2.075 & \\
\hline & Parit Tokaya & 0.0672 & 1.442 & 44.206 \\
\hline \multirow[t]{2}{*}{ Wibowo (2017) } & Sei Jawi & 0.02948 & 3.685 & \\
\hline & Parit Tokaya & 0.04162 & 0.893 & 10.687 \\
\hline
\end{tabular}

\section{Kesimpulan}

Berdasarkan hasil observasi lapangan pada Parit Sungai Jawi dan parit Tokaya Kota Pontianak, untuk penentuan koefisien kekasaran saluran, maka dapat ditarik kesimpulan Nilai koefisien kekasaran (n) Manning didasarkan mekanisme perlawanan aliran atas pergerakan dasar dengan pemisahan radius hidraulik diperoleh hasil yang lebih baik, untuk kesalahan absolut parit Sungai Jawi $(1.733 \%)$ dan Parit Tokaya (10.687\%). Penggunana rumusan ini dapat digunakaa dalam menghitung kecepatan maupun debit aliran.

\section{Ucapan Terima Kasih}

Terima kasih disampaikan kepada Fakultas Teknik Jurusan Teknik Sipil Universitas Tanjungpura Pontianak, yang telah mendanai keberlangsungan jurnal ini.

\section{Daftar Pustaka}

Al Adili, A. (2016). Investigation of the Effect of Manning Roughness on Froude Number in Subcritical Flow. Journal of Construction and Building Materials, 1(1).

Ansari, K. (2011). Boundary Shear Stress Distribution and Flow Structures in Trapezoidal Channels.

Best, J. (2005). The Fluid Dynamics Of River Dunes: A Review And Some Future Research Directions :Fluid Dynamics Of River Dunes. Journal of Geophysical Research: Earth Surface, 110(F4). doi:10.1029/2004JF000218 
Bilgil, A., \& Altun, H. (2008). Investigation Of Flow Resistance In Smooth Open Channels Using Artificial Neural Networks. Flow Measurement and Instrumentation, 19(6), 404-408.

Brownlie, W. R. (1981). Prediction Of Flow Depth And Sediment Discharge In Open Channels.

Chow, V. T. (1959). Open-Channel Hydraulics (Vol. 1). McGraw-Hill New York.

Greco, M., Mirauda, D., \& Plantamura, A. V. (2014). Manning's Roughness through the Entropy Parameter for Steady Open Channel Flows in Low Submergence. Procedia Engineering, 70, 773-780.

Griffiths, G. A. (1989). Form Resistance In Gravel Channels With Mobile Beds. Journal of Hydraulic Engineering, 115(3), 340-355.

Hölscher, R. (2016). Development Of A New Bedform Predictor.

Jarrett, R. D. (1985). Determination Of Roughness Coefficients For Streams In Colorado. US Geological Survey.

Kitsikoudis, V., Sidiropoulos, E., Iliadis, L., \& Hrissanthou, V. (2015). A Machine Learning Approach For The Mean Flow Velocity Prediction In Alluvial Channels. Water Resources Management, 29(12), 4379-4395.

Limerinos, J. T., \& California. Dept. of Water Resources. (1970). Determination Of The Manning Coefficient From Measured Bed Roughness In Natural Channels.

Mark, C. F. (2009). A Semi-Analytical Model For Form Drag Of River Bedforms. University of Twente [Host].

Md Ali, Z., \& Saib, N. A. (2011). Influence of Bed Roughness in Open Channel.

Morvan, H., Knight, D., Wright, N., Tang, X., \& Crossley, A. (2008). The Concept Of Roughness In Fluvial Hydraulics And Its Formulation In 1D, 2D And 3D Numerical Simulation Models. Journal of Hydraulic Research, 46(2), 191-208.

Naqshband, S. (2014). Morphodynamics Of River Dunes: Suspended Sediment Transport Along Mobile Dunes And Dune Development Towards Upper Stage Plane Bed.

Nohani, E., \& Bakhtiari, M. (2014). Determining The Stage-Discharge Curve And Changing It Into A Regression Equation Using Hydraulic Software. Int. J. Res. Rev. Appl. Sci. 21, 1. International Journal of Research and Reviews in Applied Sciences, 21(1), 1.

Pramono, G. H. (2005). The Study Of Bedforms And Equivalent Roughness Sizes In The Central Dithmarschen Bight.

Putro, H., \& Hadihardaja, J. (2015). Variasi Koefisien Kekasaran Manning (n) pada Flume Akrilic pada
Variasi Kemiringan Saluran dan Debit Aliran. Media Komunikasi Teknik Sipil, 19(2), 141-146.

Shen, H. W., Fehlman, H. M., \& Mendoza, C. (1990). Bedform Resistances in Open Channel Flows. Journal of Hydraulic Engineering, 116(6), 799815.

Van der Mark, C. (2009). A Semi-Analytical Model For Form Drag Of River Bedforms. University of Twente, the Netherlands.

Wang, S., \& White, W. R. (1993). Alluvial Resistance in Transition Regime. Journal of Hydraulic Engineering, 119(6), 725-741. doi:10.1061/(ASCE)0733-9429(1993)119:6(725)

Wibowo, H, Suripin, J Kodoatie, R., \& Isdiyana. (2017). Hubungan Bentuk Konfigurasi Dasar Saluran Terhadap Koefisien Kekasaran Dasar Material Non Kohesif. Https://Scholar.Google.Co.Id.

Wibowo, Hari. (2015). Analisa Perubahan Geometri Penampang Sungai Menggunakan HEC-6 untuk Menaksir Debit Sedimen pada Sungai Citanduy di Jawa Barat. Media Komunikasi Teknik Sipil, 19(2), 191-197.

Wigati, R., \& Kironoto, I. B. A. (2008). Perubahan Gradasi Material Sedimen Terangkut Terhadap Material Dasar Butiran Tidak Seragam.

Yen, B. C. (2002). Open Channel Flow Resistance. Journal of Hydraulic Engineering, 128(1), 2039. 